\title{
Separation of blood coagulation factors II, VII, IX and X by cel filtration in the presence of Dextran blue
}

Citation for published version (APA):

Swart, A. C. W., \& Hemker, H. C. (1970). Separation of blood coagulation factors II, VII, IX and X by cel filtration in the presence of Dextran blue. Biochimica et Biophysica Acta-general Subjects, 222(3), 692695. https://doi.org/10.1016/0304-4165(70)90203-5

Document status and date:

Published: 29/12/1970

DOI:

10.1016/0304-4165(70)90203-5

Document Version:

Version created as part of publication process; publisher's layout

\section{Please check the document version of this publication:}

- A submitted manuscript is the version of the article upon submission and before peer-review. There can be important differences between the submitted version and the official published version of record.

People interested in the research are advised to contact the author for the final version of the publication, or visit the DOI to the publisher's website.

- The final author version and the galley proof are versions of the publication after peer review.

- The final published version features the final layout of the paper including the volume, issue and page numbers.

Link to publication

\footnotetext{
General rights rights.

- You may freely distribute the URL identifying the publication in the public portal. please follow below link for the End User Agreement:

www.umlib.nl/taverne-license

Take down policy

If you believe that this document breaches copyright please contact us at:

repository@maastrichtuniversity.nl

providing details and we will investigate your claim.
}

Copyright and moral rights for the publications made accessible in the public portal are retained by the authors and/or other copyright owners and it is a condition of accessing publications that users recognise and abide by the legal requirements associated with these

- Users may download and print one copy of any publication from the public portal for the purpose of private study or research.

- You may not further distribute the material or use it for any profit-making activity or commercial gain

If the publication is distributed under the terms of Article $25 \mathrm{fa}$ of the Dutch Copyright Act, indicated by the "Taverne" license above, 


\section{BIOCHIMICA \\ BIOPHYSICA ACTA}

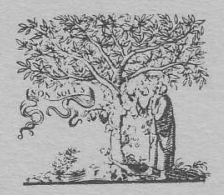

ELSEVIER PUBLISHING COMPANY Amsterdam _ London _ New York 


\section{Separation of blood coagulation factors II, VII, IX and X by cel filtration in the presence of Dextran blue}

When a preparation containing the blood coagulation factors II, VII, IX, and X, to which Dextran blue had been added, was chromatographed on Sephadex G-Ioo and $\mathrm{G}-200$ in $0.15 \mathrm{M}$ sodium acetate $(\mathrm{pH} 7.0)$ it was observed that in addition to Dextran blue, prothrombin (factor II) and factor IX activity were eluted in the void volume of the column. Chromatography in $0.5 \mathrm{M}$ sodium acetate $(\mathrm{pH} 7.0)$ failed to show this effect. These observations suggest an ionic-strength-dependent binding of prothrombin and factor IX to Dextran blue.

When chromatography was carried out in o.or M sodium acetate, factors VII and $\mathrm{X}$ interacted with Dextran in an analogous way at this low ionic strength. Gel filtration of the same material in the absence of Dextran blue in 0.0I-0.50 M sodium acetate ( $\mathrm{pH}$ 7.0) does not show elution of any activity in the void volume. On Sephadex G-200, in the absence of Dextran blue, factors II, IX, and X elute together. The elution volume of factor VII is marginally greater. This difference is much more pronounced on Sephadex G-IOo. A comparable phenomenon has been described for yeast pyruvate kinase, which forms a complex with Dextran blue depending on the ionic strength of the medium ${ }^{1}$.

Ionic-strength-dependent binding of the coagulation factors is demonstrated in the experiments illustrated in Figs. I-3. The coagulation factors preparation used in these experiments was obtained as follows: human acid-citrate-dextrose plasma was adsorbed with $0.5 \%(\mathrm{w} / \mathrm{v})$ aluminium hydroxide. The adsorbent was washed with one-tenth of the plasma volume $0.3 \mathrm{M}$ sodium-EDTA ( $\mathrm{pH}$ 8.0) and o.I M sodium 
citrate ( $\mathrm{pH} 8.0$ ) and the adsorbed coagulation factors, together with contaminating proteins, were eluted with one-tenth of the plasma volume $0.25 \mathrm{M}$ sodium-potassium phosphate ( $\mathrm{pH}$ 8.0). The eluate was further purified by the addition of saturated $\left(\mathrm{NH}_{4}\right)_{2} \mathrm{SO}_{4}$ solution at $\mathrm{pH}$ 8.o. The fraction precipitating between 40 and $60 \%$ saturation was taken and submitted to gel filtration on Sephadex G-Ioo in 0.02 M sodiumpotassium phosphate o.I M sodium chloride $\left(\mathrm{pH}\right.$ 6.8). The temperature was $4^{\circ}$ throughout.

Although factor VII is partially separated from the other coagulation factors by the gel filtration, all fractions with coagulation factor activity were pooled. The preparation thus obtained had an absorbance at $280 \mathrm{~nm}$ of $\mathrm{r} .4$ and contained $500 \%$ factor II, I340\% factor VII, 350\% factor X and I75\% factor IX. By definition, I $00 \%$ of any coagulation factor is the activity found in normal plasma from at least 30 healthy normal individuals (mean age around 30 years; sex ratio $I: I$ ), freed of platelets by centrifugation for $30 \mathrm{~min}$ at $\mathrm{I} 2500 \times \mathrm{g}$ and stored at $-20^{\circ} \mathrm{C}$. Factor II was determined by the one-stage method of KolLER et al. ${ }^{2}$. Factor VII was assayed with a reagent prepared according to the method of LECHNER AND DEUTSCH ${ }^{3}$, and factor X with a reagent made by mixing Seitz-filtered plasma prepared according to the method of BACHMANN et al. ${ }^{4}$ with factor VII purified as described in the present communication. Factor IX was determined by the method of VELTKAMP et al. ${ }^{5}$ using congenitally factor IX-deficient plasma as a reagent. The specificity of the artificially deficient reagents was checked by comparison with congenitally deficient plasmas. All chromatography was carried out at $4^{\circ}$. One set of experiments was performed on $96 \mathrm{~cm}$ $\times 2.5 \mathrm{~cm}$ columns filled with Sephadex G-Ioo in sodium acetate buffers of different ionic strength at $\mathrm{pH} 7.0 .5-\mathrm{ml}$ samples of the coagulation factor preparation to which $1.25 \mathrm{ml}$ of a Dextran blue solution of $20 \mathrm{mg} / \mathrm{ml}$ in distilled water had been added, were chromatographed. Samples were not dialyzed against the buffer in which the column was poured. The flow rate was $3-6 \mathrm{ml} / \mathrm{cm}^{2}$ per $\mathrm{h}$. Results obtained in o.or M and $0.15 \mathrm{M}$ sodium acetate are shown in Figs. I and 2.
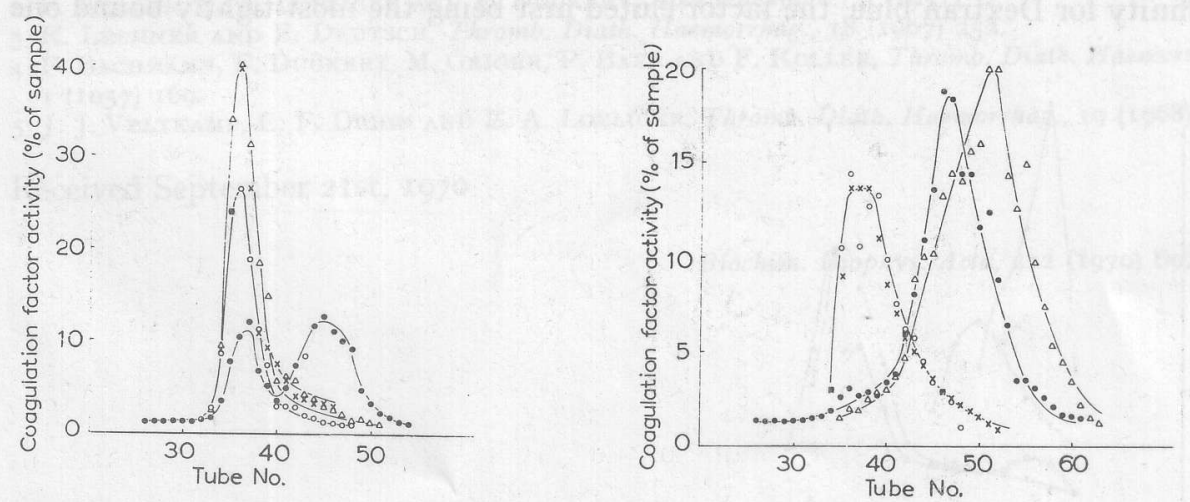

Fig. I. Chromatography of the coagulation factors II, VII, IX and X on Sephadex G-Ioo together with Dextran blue in $0.01 \mathrm{M}$ sodium acetate, pH 7.0. For experimental details see text. $\mathrm{O}-\mathrm{O}$, factor II; $X-X$, factor IX; -0 , factor $X ; \Delta-\triangle$, factor VII.

Fig. 2. Chromatography of the coagulation factors II, VII, IX and X on Sephadex G-Ioo together with Dextran blue in o.15 $\mathrm{M}$ sodium acetate, $\mathrm{pH}$ 7.0. For experimental details see text. $\mathrm{O}-\mathrm{O}$, factor II; $X-X$, factor IX; - , factor X; $\triangle-\Delta$, factor VII. 
At $0.01 \mathrm{M}$ sodium acetate, all factors except the larger part of factor $\mathrm{X}$ elute with the Dextran blue. The double peak of factor X activity means that part of the factor $\mathrm{X}$ molecules is free and part is bound to the Dextran blue. The capacity of Dextran blue for factor $\mathrm{X}$ binding under these circumstances appears to be limited. A very small residual capacity of Dextran blue for factor $\mathrm{X}$ at $0.15 \mathrm{M}$ may be the explanation for the small peak of factor $\mathrm{X}$ activity eluting with the void volume at this ionic strength. Another possible interpretation would be that factor $\mathrm{X}$ interacts with the factors II or IX bound to Dextran blue. With the same preparation of coagulation factors, the reproducibility of the method is very good. When working with different preparations, the results are also reproducible provided that the amount of protein applied to the column is not too large because the Dextran blue has limited capacity. Overloading will result in partial or total overlapping of the second peak by the first peak.

Preliminary results of rechromatography of material first chromatographed in the presence of Dextran blue and separated from it as described below, by means of DEAE-cellulose, indicate that in principle the same elution pattern as with the original preparation is again obtained.

Another experiment was performed as follows: A $96 \mathrm{~cm} \times 2.5 \mathrm{~cm}$ bed of Sephadex $\mathrm{G}-200$ was poured in a column in $0.5 \mathrm{M}$ sodium acetate ( $\mathrm{pH}$ 7.0). A gradient $(2 \times 100 \mathrm{ml})$ to $0.0 \mathrm{I} \mathrm{M}$ sodium acetate $(\mathrm{pH} 7.0)$ was introduced into the column, followed by the sample, after which o.or $\mathrm{M}$ sodium acetate ( $\mathrm{pH} 7.0$ ) was fed into the column. All solutions contained I $\mathrm{mg} / \mathrm{ml}$ Dextran blue. The sample was composed of $5 \mathrm{ml}$ of the coagulation factor preparation and $0.25 \mathrm{ml}$ of a solution of Dextran blue, $20 \mathrm{mg} / \mathrm{ml}$ in distilled water. The flow rate was $4 \mathrm{ml} / \mathrm{cm}^{2}$ per h. The sample was not dialyzed against 0.0 I $\mathrm{M}$ sodium acetate ( $\mathrm{pH}$ 7.0).

Fig. 3 shows the resulting elution pattern. The coagulation factors overtake the gradient, travelling at first with the speed of Dextran blue, to which they are bound as long as the ionic strength is low, but become dissociated when the ionic strength rises, thereafter moving at reduced speed. The order of elution thus reflects the order of affinity for Dextran blue, the factor eluted first being the most tightly bound one

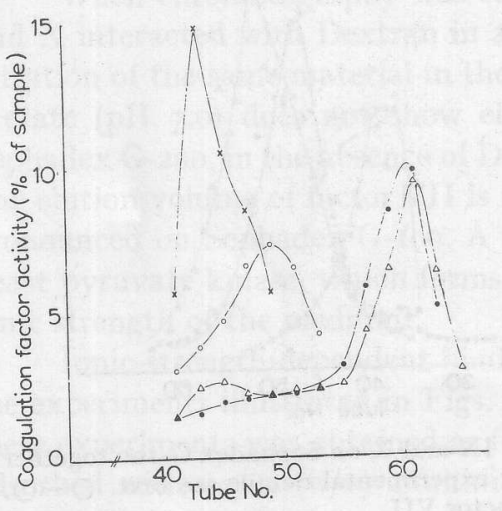

Fig. 3. Gradient chromatography of the coagulation factors II, VII, IX and X on Sephadex G-IOO a medium containing Dextran blue. A gradient of 0.5 to 0.0 I M sodium acetate ( $\mathrm{pH} 7.0)$ was made in the column as indicated in the text. $\bigcirc-O$, factor II; $X-X$, factor IX; - , factor $\mathrm{X}$; $\triangle-\triangle$, factor VII. 
The results suggest that this is factor IX. The affinity for Dextran blue as observed in these experiments thus decreases in the following order: factor IX, factor II, factors VII and X.

On a preparative level, the method is suitable for separation of factor $\mathrm{X}$ from factors II and IX, and is preferably applied to preparations from which factor VII has already been removed by gel filtration on Sephadex G-I00 in 0.02 M sodiumpotassium phosphate, o.I M sodium chloride ( $\mathrm{pH}$ 6.8) and DEAE-Sephadex chromatography. The ion-exchange chromatography is started in the same buffer as the G-IOo gel filtration. Elution of adsorbed proteins is brought about by a linear gradient to $0.02 \mathrm{M}$ sodium-potassium phosphate, $\mathrm{I} \mathrm{M}$ sodium chloride ( $\mathrm{pH}$ 6.8). This procedure also yields factor VII free of any other activities.

The Dextran blue-coagulation factor complexes can be dissociated in two ways. One possibility is rechromatography on Sephadex G-I0o, G-I50, or G-200 in buffers of high ionic strength. I M sodium acetate ( $\mathrm{pH}$ 7.0) brings about complete dissociation. Another possibility is to pass the complex through a DEAE-cellulose column. A $5 \mathrm{~cm} \times \mathrm{I} .5 \mathrm{~cm}$ column equilibrated with $0 . \mathrm{I}_{5} \mathrm{M}$ sodium acetate $\mathrm{pH} 7.0$ was used. The Dextran blue binds very tightly to the ion exchanger. $0.5 \mathrm{M}$ sodium acetate $(\mathrm{pH} 7.0)$ elutes the coagulation factors while leaving the Dextran blue adsorbed.

These experiments were carried out with financial aid from the Netherlands Organisation for Pure Scientific Research and the Netherlands Foundation for Chemical Research (ZWO/SON).

Laboratories for Blood Coagulation and

A. C. W. SWART

Cardiovascular Biochemistry,

H. C. HEMKER

Department of Internal Medicine,

University Hospital,

Leiden (The Netherlands)

I R. Haeckel, B. Hess, W. Lauterborn and K. H. Wüster, Z. Physiol. Chem., 349 (I968) 699.

2 F. Koller, E. A. Loeliger and F. Duckert, Acta Haematol., 6 (195I) I.

3 K. Lechner and E. Deutsch, Thromb. Diath. Haemorrhag., I8 (I967) 252.

4 F. Bachmann, F. Duckert, M. Geiger, P. Baer and F. Koller, Thromb. Diath. Haemorrhag., I (I957) I69.

5 J. J. Veltkamp, E. F. Drion and E. A. Loeliger, Thromb. Diath. Haemorrhag., ig (1968) 279.

Received September 2Ist, I970 